\title{
Rethinking social housing: Behavioural patterns and technological innovations
}

\author{
Valentina Gianfrate ${ }^{\mathrm{a},{ }^{*}}$, Chiara Piccardo ${ }^{\mathrm{b}}$, Danila Longo ${ }^{\mathrm{a}}$, Andrea Giachetta ${ }^{\mathrm{b}}$ \\ a Department of Architecture and Design, University of Bologna, viale Risorgimento 2, Bologna, Italy \\ b Department of Sciences for Architecture, University of Genoa, Stradone S. Agostino 37, Genoa, Italy
}

\section{A R T I C L E I N F O}

\section{Keywords:}

Social housing

Energy behaviour

Retrofit technologies

Occupants'

Training measures

\begin{abstract}
A B S T R A C T
The building sector accounts for $40 \%$ of energy use and $25 \%$ of $\mathrm{CO}_{2}$ emissions, mainly due to ineff cient building practices and energy consumption during the operational phase of buildings. Social housing accounts for a significant proportion of the European building stock and about $50 \%$ of the existing buildings are likely to require large-scale renovations in the coming years, meeting the current EPBD directive. This could represent an opportunity to renovate the affordable building stock, often characterized by premature disrepair, resulting in a bad perception from inhabitants and community. Significant European experiences have already shown the importance of an integrated approach finalized to the construction or renovation of social housing, leveraging on environmental sustainability, creating urban identity, adopting measures to face social disadvantage, off ering at the same time quality housing standard. In this regard, it seems necessary to match technological advancements and knowledge in energy retrofitting with social needs and habits. The implementation of energy-efficiency improvements in social housing requests support and participation of the final energy consumer. The paper investigates how to deal with knowledge gaps in the relationship between retrofit technologies and users' behaviour and possible strategic measures to increase awareness between tenants through two case studies.
\end{abstract}

\section{General framework}

The built environment accounts for a significant share of anthropogenic greenhouse gas emissions, mainly due to ineff cient building practices and energy consumption during the operational phase of buildings (Harvey, 2010). At the European level, buildings account for $40 \%$ of energy consumption and about $25 \%$ of $\mathrm{CO}_{2}$ emissions (Tommerup and Svendsen, 2006; Uihlein and Eder, 2010).

The 2010 European Directive on Energy Performance of Buildings (2010/31/EU), implementing the previous 2002 Directive (2002/91/ EC), is aimed at improving the energy effi ciency of buildings to a nearly zero-energy standard by 2020 and is expected to reduce total EU energy consumption by $5 \%$ to $6 \%$, as well as $\mathrm{CO}_{2}$ emissions by about $5 \%$ (Anonomous, 2017a). The Directive involves not only new buildings, but also existing buildings liable to significant renovation, which is representing about $70 \%$ of the building stock by 2050 (Visscher, Sartori, \&Dascalaki, 2016) and so a promising target to reduce the environmental impact of the building sector.

Research studies and applications demonstrate that retrofitting existing buildings could contribute to a significant reduction of energy consumption. For example, Ecofys explores the effects of the Energy
Performance of Buildings Directive (EPBD) on the energy effi ciency of the European existing building stock, in terms of heating energy savings, and demonstrates that the residential sector contributes for $77 \%$ through retrofitted single- and multi-family houses (Petersdorff, Boermans, \&Harnisch, 2006). Recently, a study of the Joint Research Centre (JRC) shows that the main environmental improving potential is represented by single-family houses, followed by multi-family houses, that represent the $53 \%$ and $37 \%$ of the European building stock, respectively (Nemry and Uihlein, 2008).

Significant European experiences (BedZed in London, Hammarby Sjostad in Stockolm, Malakoff Neighbourhood in Nantes) show the importance of an integrated approach at the basis of the construction or renovation of social housing, leveraging on environmental sustainability of works, creating urban identity between the inhabitants, adopting measures to face ghettoization and social disadvantage, offering at the same time quality housing standard, higher comfort levels and aff ordable using/maintenance costs. (Table 1)

Despite the great efforts spent in developing effective technological solutions for retrofitting, a number of implications dealing with energy issues, climate changes, and economic development are still underestimated (Boeri, Antonini, \&Longo, 2013). It has been observed that

\footnotetext{
${ }^{*}$ Corresponding author.

E-mail address: valentina.gianfrate@unibo.it (V. Gianfrate).
} 
Table 1

Housing models and related pilot cases (Gianfrate and Piccardo, 2016).

\begin{tabular}{|c|c|}
\hline Models & Pilot cases \\
\hline $\begin{array}{l}\text { Collective housing: } \\
\text { Addressed to specific target, satisfying housing needs of short and very short period (temporary } \\
\text { workers, facilities users, etc.). The collective housing can host public services at urban or } \\
\text { neighbourhood scale. } \\
\text { It is usually funded by public investments, but not always the promoter is the building owner. }\end{array}$ & $\begin{array}{l}\text { - Social Housing a Vallecas http://www.archdaily.com/643384/social- } \\
\text { housing-in-vallecas-vazquez-consuegra } \\
\text { - Social Housing for mine workers, Asturie } \\
\text { http://www.archdaily.com/153189/social-housing-for-mine-workers- } \\
\text { zon-e-arquitectos } \\
\text { - Edificio Residenziale Ex Berardi } \\
\text { http://www.premioinarsind.it/edizione-2010/de-appolonia-botticini- } \\
\text { edificio-residenziale-area-ex-berardi/ }\end{array}$ \\
\hline Rental brokerage services: & - Quayside Village Vancouver, CA \\
\hline $\begin{array}{l}\text { The service is direct to improve housing people independence. It include individual or } \\
\text { community projects, or offer economic assistance to support inhabitants in their inclusion } \\
\text { process, in a short-medium term project (from several months to two years) }\end{array}$ & $\begin{array}{l}\text { http:// cohousing.ca/places/canada/british-columbia/north-vancouver/ } \\
\text { bc_cohousing/ quayside-village/ } \\
\text { - Progetto Stessopiano Torino } \\
\text { http://www.stessopiano.it }\end{array}$ \\
\hline $\begin{array}{l}\text { PPP (Public-Private Partnership) - based social housing: } \\
\text { The PPP promotes an housing project at local level, with the aim to attract investments on } \\
\text { developing urban areas, in the renovation of derelict neighbourhood, with interventions at } \\
\text { building/district scale. The final objective is to improve rental and for sale dwelling provision, } \\
\text { with affordable prices and good quality solutions. (Gianfrate, Antonini, Longo, \& Copiello, 2016) }\end{array}$ & $\begin{array}{l}\text { - Cenni di cambiamento, Milano } \\
\text { www.cennidicambiamento.it/ } \\
\text { - Parma Social House, Parma } \\
\text { http://www.comune.parma.it/comune/ Pages/pagina_generica.aspx? } \\
\text { ID= 0ef7b1a9-8362-46be-8ed4-4cb6f58eb2c6 } \\
\text { - Abitiamo Insieme Ascoli, Ascoli Piceno } \\
\text { www.abitiamoinsiemeascoli.it/ } \\
\text { Luoghi Comuni, Torino } \\
\text { http://www.luoghicomuni.org }\end{array}$ \\
\hline $\begin{array}{l}\text { Community housing: } \\
\text { Direct construction of residential complexes, by inhabitants communities, joint by the common } \\
\text { desire to obtain a home. This category collects self-construction initiatives, co-housing, self- } \\
\text { refurbishment. The promoter is usually the community. All the inhabitants involved after the } \\
\text { construction have to accept the living programme, with a formal commitment of the community } \\
\text { housing rules. }\end{array}$ & $\begin{array}{l}\text { - Coin Street London www.coinstreet.org } \\
\text { - Cohousing NumeroZero Torino, http://www.cohousingnumerozero.org } \\
\text { - La corte dei girasoli, Vimercate http://www.lacortedeigirasoli.it }\end{array}$ \\
\hline
\end{tabular}

Table 2

Non technological barriers in the retrofitting of the existing building stock (Source: Barriers and possibilitiesfor a more energy efficient construction sector - SECURE Project).

\begin{tabular}{|c|c|}
\hline Non technological barrier & example \\
\hline Legal & $\begin{array}{l}\text { - Contractual } \\
\text { - Guarantee period } \\
\text { - Business agreements } \\
\text { - Local building plants } \\
\text { - Directive on energy performance }\end{array}$ \\
\hline Financial & $\begin{array}{l}\text { - Life-cycle cost } \\
\text { - Investment cost } \\
\text { - Pay-off time } \\
\text { - Impact on tax assessments } \\
\text { - Energy price }\end{array}$ \\
\hline $\begin{array}{l}\text { Organization of the sector } \\
\text { (building sector, } \\
\text { market) }\end{array}$ & $\begin{array}{l}\text { - Organization of the sector } \\
\text { - Dialogue understanding between partners } \\
\text { - Availability of technological solutions } \\
\text { - Customer demand } \\
\text { - Esthetics } \\
\text { - Cultural values }\end{array}$ \\
\hline Social & $\begin{array}{l}\text { - Social planning } \\
\text { - Public or individual energy supply provider } \\
\text { - General or individual measurements of } \\
\text { energy performance } \\
\text { - User behaviour/ comfort } \\
\text { - Cultural aspects } \\
\text { - Social aspects } \\
\text { - Age/generational aspects }\end{array}$ \\
\hline
\end{tabular}

the most critical factors that can reduce the actual number of eff cient renovation initiatives are non-technical barriers related to legal, financial, social constraints (see Table 2) strongly limiting the feasibility of the interventions much more so than the technical obstacles.

The implementation of energy-effi ciency improvements in all key sectors requires the support and participation of the final energy consumer. Behaviour and local cultural factors can drive basic energy use practices (I.P.C.C., 2014): end-users involvement is based on the consumers' knowledge on energy issues and on their awareness on the possible energy effi ciency improvement and their understanding of the costs and benefits involved in the different options.

The factors and their relations that influence behaviour and consumption practices are dynamic, strongly dependent by human elements: they change over time, conditioning consumer behaviour, so the process of consumption practices becomes somewhat irrational and to some extent unpredictable (EEA, 2013). Shove argues that there is a close relationship between behaviours and infrastructure (Shove, 2010): energy infrastructure (e.g. smart grids, heating \& cooling systems, mobility and transport systems) plays an active role in people life, but the interaction with new energy technologies and their comprehension presents lacks and delays.

One of the cause of this "lag" consists in the stressed recourse to hitech energy effi ciency measures, especially in residential sector, where the variability of requirements, habits, motivations, awareness and financial liquidity of tenants is more evident. This aspect weights on the refurbishment interventions of the built environment and on new housing constructions, considering the limits in the technological choices and their affordability.

The possible solutions consist in a combination of technical and social measures, through the adoption of user-friendly energy effi ciency systems that could facilitate the use by tenants and increase their environmental and energy awareness.

The investigation of the dimension and the value of end users behaviour, before design stage, helps to identify the best strategies to forecast and minimize negative impacts of tenant's habits on the good use and functioning of dwelling technologies, in the achievement of good performance of buildings.

The introduction of public participation strategies and user's awareness in the design process, as well as design tools and support measure for users for improving a better relationship between user and technological system (and so a better housing quality), can support more functional and contextualized choices about the technologies employed. This integrated approach support energy access strategies in the residential sector, and especially in Social Housing, which require an effective use of energy with the minimum purpose of economic and technological resources. 


\section{New living models: the social housing option}

'Home' concept, according to the definition of Ethos, ${ }^{1}$ the European Typology of Homelessness and Housing Exclusion, is characterized by three domains: physical (based on the exclusive ownership of a space); social (based on the possibility to maintain in that space satisfactory and confidential relationship), and legal (with a legal acknowledgement of enjoyments of goods).

The exclusion of one or more of these domains causes different living situations, from the extreme condition of rooflessness to living in inadequate houses. Housing poverty is a process that can affect exposed people in different stages of their life. In order to give an answer to this variable phenomenon, the welfare models and the strategies have to become flexible to be effective.

The housing problem is the result of deep changes from the demand side that request new policies able to combine economic and social aspect (the ageing of population, the increasing of number of families, the increasing of social and economic vulnerable categories, the increasing number of migrants), facilitating housing access.

For what concern the supply side, the state of art of affordable housing is often characterized by building quality compromised by costs savings objectives, low-end implementation standards, lack of maintenance operations, which produced time after time performance obsolescence in the dwellings and a bad perception from inhabitants and community.

In Italy, as established by the Law n.56/2014 "Disposal of metropolitan cities and municipality unions", one of the priority for urban development plans, is the introduction of an «infrastructure of urban and home living policies and have to make sure that social housing is developed in an eco-sustainable way, safeguarding the territory and prioritizing the renovation and the reuse of historic centres, of abandoned industrial areas and decayed housing complexes». This interaction between the urban/design project and its social management will drive the social housing model diffusion specifically located in Northern Italy. Technical and social management project were developed together from the very beginning thanks to a preliminary assessment of potential housing demands, the identification of the specific types of occupants for each project, and the definition of housing allocation criteria. In some cases the future occupants were involved in the creation of new communities to strength of mutual relations and with the aim to assume its living space as a common good, valorising it by means of revenue-producing activities and events.

Unlike in other countries, in Italy "Social Housing" is still considered an experimental field of development, deployed by social enterprises (EURICSE), though it has registered a progressive and significant increase over the last twenty years. The new law on social enterprises (n. 118/2005) corroborates this increment, assuming social housing as a possible sector of development for social enterprises (Fondazione Housing Sociale \& Fondazione Cariplo, 2009/2010), and as an opportunity, to face new housing demand, increasingly complex and fragmented and new living models needs, through:

- the improvement of the beneficiaries target, including the "grey area" (Napoli, 2015) of outsiders, members of middle class fallen into poverty, not involved in aff ordable housing programs, but not able to buy a private house

- the answer to "uncovered" needs, which are the mirror of end-users vulnerability, not caused only by the economic dimension, but also by different variables (need temporariness, disability, etc.), providing different ranges of rents (EURICSE), with the perspective to achieve a social mix of tenants, to avoid the ghettoisation of

\footnotetext{
${ }^{1}$ ETHOS, the European Typology on Homelessness and Housing Exclusion, was promoted by FEANTSA in 2005. After two-years period of analysis and review, it becomes the more important reference for housing exclusion studies in UE
}

concentrations of disadvantaged population groups;

- the identification of new financial and funding models, through a matched intervention of heterogeneous stakeholders, integrating private and public actors, creating at the same time a new "social entrepreneurship", promoted by housing cooperatives of inhabitants, social operators, foundations of banking or private entities, fostering new partnerships' models.

- the attraction of private resources (deriving from the sale of residential accommodations to different types of users, the supply of urban land or rights through recourse to balance urban development, or introduction of public funds in support of the rental guarantee (Nomisma, 2010), or to cover part of the rental prices for disvantaged people);

- the provision of a range of services to match the needs of inhabitants (especially families with social problems) and assist them, who will be integrated with neighbors (e.g. mediation of conflicts, cultural and language mediators, neighbourhood proximity services) and at the same time identifying financial tools for dwelling owners and tenants (e.g. guarantee fund for tenants when there are events that destabilize the person's life and his family such as unexpected unemployment, the loss of self-suffi ciency of a component of the family (Nomisma, 2010); backing services to find new housing solutions,etc)

Social Housing sector is an interesting field to test solutions finalized to assure the compliance between demand and supply side (Lodi Rizzini, 2013), in relation to expenditure possibility, spatial equipment, services and facilities. The capacity to accommodate multiply living models, and different tenants in terms of age and social class, is a driver to improve housing quality also in refurbishment interventions. The energy effi ciency challenge is a stimulus not only in pursuing climate benefits but also in improving social housing quality as well.

Social housing accounts for a significant proportion of the European building stock, an average of about $9,4 \%$, ranging from a minimum of $4 \%$ (Hungary) to a maximum of $35 \%$ (Netherlands), and the social housing demand is still growing (Whitehead and Scanlon, 2007). Moreover, about $50 \%$ of the existing buildings were built before the 1970 (Norris and Shiels, 2004), so it is likely that they will require large-scale renovations in the coming years, meeting the current EPBD directive. Therefore it seems necessary to match technological advancements and knowledge in energy retrofitting with social needs and habits.

\section{The energy effi ciency paradigm in affordable housing}

Although the EPBD directive clearly includes 'major renovation' (EPBD, 2010) of the existing building stock as energy-saving strategy in the building sector, it does not suggest any specific definition and transfers to the Member States the task of choosing a definition of 'major renovation' as a percentage of the surface of the building envelope or the value of the building, alternatively. Hence, at the moment the definition of 'major renovation' and its role in the improvement of the energy performance of buildings differ among the European countries. However, we can argue that social housing is fully involved in the European energy-saving policies because of its significant building stock.

The majority of energy consumed in the European residential buildings is used for space heating $(57 \%)$, followed by domestic hot water $(25 \%)$ and electricity for household appliances (11\%) (Chwieduk, 2003).

Various energy-saving measures can be applied to existing buildings, depending on their construction technology, site and local climate, as well as cost-effective retrofit opportunities and regulatory framework. The literature also suggests different retrofitting measures, usually divided in energy saving and energy conservation (energy-efficient building envelope) practices (Bradford and Schleich, 2012; Xing, 
Hewitt, \& Griff ths, 2011), the first one also including renewable energy applications. The same retrofitting measures can also be divided in demand- and supply-side management (Ma, Cooper, Daly, \& Ledo, 2012), in a building management perspective.

Whilst in privately owned houses the householders decide possible retrofitting measures and are expected to be conscious of their buildings' operation, in social houses retrofitting measures are usually undertaken by the housing company, so they require to be communicated, assimilated and accepted by the tenants. The role of users (especially, social housing tenants) can influence the operation of energy-saving building technologies and so the building energy consumption (Hong, Taylor-Lange, D’Oca, \& Yanc Da Corgnati, 2016; Pothitou, Kolios, Varga, \&Gu, 2016), as well as it can contribute to energy saving by 10-30\% (Hong et al., 2016; Steemers and Yun, 2009; Yohanis, 2012) because of habitual behavioural changes (Pothitou et al., 2016).

The use of emerging technologies in social housing may conflict with tenants' habits, contributing to a gap between designed and actual performance. Retrofit technologies in social housing require a deep reflection on social and cultural implications and users' behaviour should be taken into account since the design stage. With this purpose, many studies describe behavioural patterns as the relationship between the occupants' final energy use and their values or habits.

New technologies may also represent additional challenges for social housing tenants, especially older people (Brown, Swan, \& Chahal, 2014) that are not always able to manage such technological systems and to understand their advantages. Moreover, the use of new technologies and related energy-savings may result in rebound effect, encouraging occupants to a greater energy consumption and major use of household appliances (Jenkins, 2010). Therefore social acceptance and awareness of retrofit technologies is important both to ensure the living comfort of the users and the correct operation of retrofitting interventions.

Table 3 illustrates major possible retrofitting measures reducing energy consumption from a user-technology relation perspective. In particular, retrofitting measures are divided in four quarters, according to the consciousness required to the users (social housing tenants) for properly managing retrofit technologies (horizontal axis), and the type of retrofit technology (vertical axis). 'High-tech retrofit' pertains to retrofitting measures based on the use of additional devices for producing or saving electricity, sometimes themselves using electricity to operate (Ryghaug and Sørensen, 2009). 'Low-tech retrofit' pertains to retrofitted measures based on the energy performance of the building and its subsystems, usually integrating bioclimatic strategies, without requiring electricity or fossil fuel to operate (Alexander and Yacoumis, 2016; Bradford and Schleich, 2012; Brown et al., 2014; Chwieduk, 2003; Hong et al., 2016; Jenkins, 2010; Ma et al., 2012; Pothitou et al., 2016; Ryghaug and Sørensen, 2009; Steemers and Yun, 2009; Xing et al., 2011; Yohanis, 2012). 'High-tech' and 'low-tech' retrofitting measures substantially correspond to the so-called 'active' and 'passive' building systems, respectively, even if we prefer not to use the adjectives 'active' and 'passive' in order to avoid possible confusion with the role of users in the operation of retrofit technologies. Details of these retrofitting measures can also be found in Refs (Boeri and Fabbri, 2014; Giachetta, Magliocco, \&Piccardo, 2014b; Kolaitis et al., 2013; Xing et al., 2011). The operation of high- and low-tech retrofit technologies requiring a higher user consciousness may be affected by behaviour and habits of the tenants. Besides high- and low-tech retrofit technologies that need a lower energy consciousness of the users are expected to perform according to the retrofit design. Technical solutions, as thermostat and heat recovery systems, which limit the occupants' interaction with technology could mitigate wasted energy but, at the same time, they could encourage not energy-conscious behaviour, resulting in the rebounded effect (Hong et al., 2016).

However high- and low-tech retrofit technologies requiring high user consciousness can be applied together with proper strategies aimed at improving the users' knowledge and enhancing their interaction.

\section{The end-users'role}

In $2011,9.8 \%$ of households in the EU could not aff ord to heat their home adequately, whilst $8.8 \%$ of households were in arrears on their utility bills (Thomson and Snell, 2013). One of the ways of addressing this challenge is through social tenants' behavioural change, by increasing their understanding and engagement in energy efficiency.

The EU Commission (E.U. Commission, 2008) identifies 'the lack of consumer awareness' as one of the main obstacles to achieving the target on reducing energy by $20 \%$. Creating awareness is seen as one of a number of enabling factors, which include, external constraints on behaviour, financial, technical and organisational resources, the improvement of new skills and the development of new user-friendly tools. The new European Commission programs, as Horizon 2020 are supporting many projects in the field of energy saving, with the aim to improve inhabitants behaviour and to help Europe to meet the key targets linked to energy.

Recent research studies have shown a gap between energy predictions and reality, and a limited understanding of the interaction between housing energy effi ciency refurbishment and occupant behaviour with high variations between domestic energy consumption, even 'between similar households in nominally identical houses' (Banfill and Peacock, 2007). The key patterns that frequently affecting energy behaviour (Gill, Tierney, Pegg, \&Allan, 2010; Janda, 2009; Smith and Pett, 2005; Stevenson and Leaman, 2010) are connected to access to knowledge and skills; nature of technical intervention; habits; external circumstances; quality of technical intervention; convenience of technology; and thermal comfort.

The difficulty of predicting occupant behaviour is a direct consequence of the increased complexities in buildings and weather, but it is also a failure on the part of building professionals to adequately recognise and take variations in occupant activities into account (Elzenga, Voordijk, Hartmann, \& Salet, 2010). This diffi culty has negative outcomes starting from the analysis of building performance: any prediction of energy efficiency retrofit performance with regards energy

Table 3

Major retrofitting measures from a user-technology relation perspective.

\begin{tabular}{|c|c|}
\hline High-tech retrofit - low user consciousness & High-tech retrofit - high user consciousness \\
\hline $\begin{array}{l}\text { - -Renewable energy supply systems } \\
\text { - -Energy efficient appliances and lighting } \\
\text { - Efficient taps } \\
\text { - Thermal insulation solutions (i.e. External Thermal Insulation Composite Systems, attic } \\
\text { insulation) } \\
\text { - Airtightness } \\
\text { - Thermal storage systems } \\
\text { - Energy-efficient windows (multi-glazed pane, gas fill, low-e coating, etc.) } \\
\text { Low-tech retrofit - low user consciousness }\end{array}$ & $\begin{array}{l}\text { - Mechanical ventilation with heat recovery (MVHR) } \\
\text { - Thermostat and other manual control devices } \\
\text { - Smart technologies } \\
\text { - Thermal insulation solutions (i.e. internal thermal insulation, cavity wall } \\
\text { insulation) } \\
\text { - Passive heating and cooling systems (greenhouses, Trombe-Michel walls, roof } \\
\text { pound, etc.) } \\
\text { - Green walls and roofs } \\
\text { - User-controlled shading devices } \\
\text { Low-tech retrofit - high user consciousness }\end{array}$ \\
\hline
\end{tabular}


saving become complex, further complicated by issues of comfort 'takeback' (Milne and Boardman, 2000) and 'rebound' (Hertwich, 2005; Galvin, 2014).

Building characteristics and fabric could affect energy consumption via the thermal properties, and the interaction between the user and the building's systems, but the energy performance of a building and comfort perception is also significantly affected by the user behaviour like the setting of room thermostats and opening/closing windows. All these elements have an influence on the large gap between simulated and measured building energy use (Lomas, Martin, \&Bloomfield, 1997;Pedrini, Westphal, \& Lamberts, 2002; Tronchin and Fabbri, 2008).

One of the main reasons of these significant differences is neglecting or over-simplifying the influence of occupants' behaviour that varies by time and typology of occupants. For example, there are significant interactions between who lives in the buildings and the ICT based control systems. The occupants' expectation of comfort or satisfaction with the building environment drives the occupant to perform different controls, such as adjusting the thermostat in spaces, opening windows for ventilation, turning on lights, pulling down the window blinds, and consuming domestic hot water. Different occupants' behaviours have various effects on building performance and energy use. Research on occupant behaviour in relation to energy consumption should look at the potential effects of both building characteristics and household characteristics (demographics). However, how the energy performance characterization and simulation models can be integrated appear and remain still unsolved.

There is a lack in the existing softwares to include the influence of occupants' behaviour in the final energy performance of buildings in the operational environment. The discrepancy reasons between simulated energy consumes and real ones is linked to the limits of simulation software, that are able to describe only the control action through modelling static scenarios, not adapt to describe the dynamic nature of occupant's behaviour models. The most common softwares describe occupants presence and its action on the building, but the human behaviour is more complex (Hoes, Hensen, Loomans, Vries de, \& Bourgeois, 2009).

Technology and behaviour are closely interwoven in many respects (Midden, Kaiser, \&McCalley, 2007). The study developed by Midden, Kaiser and Calley describes four main roles that technology plays:

- intermediary, where the technology is a conduit between the behaviour an individual carries out to reach a goal;

- amplifier, where the technology amplifies, enhances or extends the individuals goal attainment;

- determinant, where the technology creates context or environment surrounding the individual, thus influencing or shaping behaviour through the technology's existence, and;

- promoter of environmentally significant behaviour, where technology is specifically designed to promote behavioural choices leading to the conservation of natural resources.

The improvement of the occupancy and usage behavioural pattern, could be achieved through education and training initiatives to improve the understanding of tenants, which can produce as outcomes the reduction of the carbon footprint as well as helping to eliminate the fuel poverty.

In Social Housing contests it is possible to act on tenants' preferences for lower/higher set point temperatures; duration of heating period(s); self regulating systems by occupants, heating/ cooling zoning, expecially in the contexts in which. tenants cannot afford to pay for their electricity/gas usage (i.e. fuel poverty). Adopting a correct behaviour, spending the same amount on fuel as before, they can obtain a better thermal comfort for the same cost.

Different EU projects investigated the causes linked to tenants behaviour for what concern the effective discrepancy between simulated and measured building energy use in social housing complex, such as
BECA (The Balanced European Conservation Approach Project. 2011-2014) (Anonomous, 2017b), and CAABE (Capitalizing Alpine Building Evaluation Experiences. 2012-2015) (Anonomous, 2017c), or the research studies carried out by Department for Environment Food \& Rural Affairs (Defra) in UK (Collier et al., 2010). The CAABE project include two Italian case studies, in Bolzan and in Turin.

In Bolzan the Casanova District is a complex realized following CasaClima $^{2}$ standard. During the operational period, the results of a monitoring initiative based on direct interviews emerged the un-satisfaction of tenants for what concern the presence of thermal bridges, the indoor hot temperatures during summers, the increase of the whole building costs for heating (increased from 800 euro to 3000 euro). The public administration and the building companies started a series of initiatives to improve the buildings' fabric conditions. At the same time the interview campaign reveals the higher consumes expecially in the more complex (in reference to the technologies adopted) buildings, for example equipped with VMC. The research showed a wrong occupants' management of the system, with no benefit deriving from the heat recovery.

Another criticism is linked to the higher consumes for heating despite of the project elaboration's previsions. The simulation considered an indoor temperature of $20^{\circ}$ degrees, but the monitoring showed the habits to adopt a $23^{\circ}$ indoor temperature in the dwellings.

The other cases are comprehensive of different social housing complexes in Turin. One of these is the via Arquata building. Also in this case the results of a questionnaire campaign between occupants get to emerge the real situation for what concern thermal perception, humidity, air infiltrations, moulds, air quality. The human behaviour was a cause of the loss of energy performance of the buildings, expecially linked with an incorrect management of the air turnover, and a wrong set of the temperature during winter.

In both these cases the results of the interviews were adopted as a starting point for the meetings with the occupants, to promote a training module presenting new ways to reduce energy consumes, and improve their comfort indoor. This module contained information about:

- Thermostat use

- Exhaust air exchange

- Thermal comfort

- Air quality

The gaps in knowledge around how energy related behaviour can be solved through the adoption of a common strategy to increase awareness. This strategy could include different tools such us ICT devices to receive messages through energy monitors, with a direct feedback about the own consumes' profile; gamification during specific awareness events at neighbourhood/block level, to motivate people (e.g. competitions), giving feedback and goal setting (Bakhaus and Heiskanen, 2013) acting not only on individual behaviour but addressing the local community and wider society to a more consciousness energy habit.

Tailored learning programs could enable tenants to adjust their levels of competence, promoting at the same time a more conscious energy use practice, reconfiguring their routines with a focus on convenience aspects. And at the same time emphasizing the importance of designing user friendly devices and accompanying monitoring feedback with appropriate guidance and support, information and advice ensure the effectiveness of the process (Darby, 2010).

\footnotetext{
2 The Casaclima certification has been the first in Italy introducing the energy rating for buildings and it is mandatory in the Provice of Bolzano
} 
5. Approach and application in two case studies: savona and bologna

\subsection{A passive solar retrofit in savona (IT)}

The passive solar retrofit of residential buildings in Savona was part of a wide urban requalification, completed in 2013 and aimed at improving the living standards in the urban area of Piazzale Moroni. The project proposed the energy retrofitting of 15 apartment buildings and the requalification of public spaces. The municipality of Savona, in partnership with the public housing company ARTE (Regional Territorial Agency for Building), funded the requalification works in the framework of the programme 'District II Contract' (Ministerial Decree 2522/2001 and 30/2002), for the total amount of about 5 million euros. This national funding programme was aimed at financing requalification projects of urban areas affected by urban disrepair and poor design, lack of social infrastructure and social vulnerability. Details of the urban requalification and building retrofitting can also be found in Refs (Giachetta, 2012; Giachetta, Piccardo, \& Magliocco, 2014a; Giachetta et al., 2014b; Magliocco and Giachetta, 2011).

The residential buildings, built in the early 70's, were affected by several functional problems, common to many urban suburbs: lack of urban planning and infrastructure; random location of buildings in relation to climate conditions, poor technological quality due to low cost building, thermal discomfort due to relevant heat losses and moisture accumulation. The neighbourhood was also affected by social problems, like a high percentage of not self-suffi cient elderly people.

The retrofitting project involved 15 buildings, owned by ARTE, and was aimed at replacing unsafe building materials (i.e. removal of concrete-asbestos wall cladding on the north façades), insulating external walls and renovating building façades. Moreover, the national announcement enhanced the use of experimental retrofitting measures for reducing energy consumption for operation, complying with specific regional guidelines. In Savona three pilot buildings were selected because of their suitable solar irradiation and retrofitted with passive solar heating systems, such as solar greenhouses and Trombe-Michel walls, in order to reduce the energy use for space heating. One building (building A) was retrofitted with solar greenhouses on the South façade with a total heated volume of $60 \mathrm{~m}^{3}$ (Fig. 1); the other two buildings (buildings B and C) were retrofitted with both solar greenhouses, enclosing the existing balconies, and Trombe-Michel walls on the South façade. A $20 \mathrm{kWp}$ photovoltaic system was also installed on the roof of one of the three buildings, providing an average of $1 \mathrm{~kW}$ for each apartment.

Operable vents and special vented doors giving access to the greenhouses are placed in the external walls to permit heat to flow directly into the room during the day (in winter). This solution also ensures thermal insulation of the living spaces during the night, in winter, and the day, in summer, considering the lack of thermal lag. Moreover, such ventilated passive solar systems suit well the needs of users, since they are mostly elderly people who spend most of the daytime in their lodgings.

In order to avoid overheating in summertime, specially-designed shading devices were applied to the passive solar systems (adjustable roller blinds to the greenhouses and fixed brise-soleil to the TrombeMichel walls). Electrical air fans controlled by a winter/summer switch were also placed into the sunspace of the Trombe-Michel walls enhancing the leakage of heated air during summer.

As mentioned earlier, these passive solar systems can be categorized as low-tech retrofit technologies requiring high user consciousness to be properly used, because they involve some user-controlled devices. Indeed, the solution adopted for Trombe-Michel walls (Figs. 2 and 3) resulted from careful consideration during the design stage, in cooperation with the funding authorities. If users are used to manage roller blinds, such as those of greenhouses, to avoid overheating in summer, the management of possible sun shading devices and air fans of the Trombe-Michel walls could be more complex. This happens because there is no direct perception of these elements inside the lodgings (apart from the presence of air vents). Therefore the design team decided to use fixed brise-soleil and a simple ventilation system, easily understandable by users.

A series of meetings in the social lab 'District II Contract' were organized by the funding authorities in order to encourage tenants to take up retrofitting measures. In addiction, an information campaign was also addressed to all the tenants of the retrofitted buildings, in order to communicate basic information to those people who did not attend the meetings, so ensuring a greater informed consent. The information campaign was based on traditional means, as mails and public advertisement on the main entrances of the residential buildings, using a simple, not technical, information. During the retrofitting works, the local off ces of the building contractor were placed next to the social lab 'District II Contract' and it represented another local reference point.

Certain retrofitting solutions had to be reconsidered as they were hardly manageable during the construction stage. For example, the installation of air vents to control internal/external convection heat transfer control was actually very complex, especially when users did not leave their apartments during the daytime, because of the presence of furniture which had to be moved and the dust generation from the demolition activities.

The mentioned difficulties in managing new systems by users has also raised interest in ARTE, which has designated the Department of Architecture and Design (DAD) of the University of Genoa to draw up a user manual for passive solar heating systems, three years later the solar retrofit. In relation to this task, the department has also carried out a monitoring campaign to evaluate the effective operation of passive solar heating systems. The research group carried out several surveys in occupied and not-occupied apartments, aimed at verifying the conditions of the greenhouses and Trombe-Michel walls. It also carried out thermographic surveys, aimed at evaluating the effectiveness of the external insulation and the possible presence of the 'thermal bridges', as well as the monitoring of the indoor air temperature in the solar-retrofitted apartments during winter and summer, using temperature data loggers and anemometer to measure low air velocities.

The below main operation problems were identified:

- the surveys highlighted differences between designed and actual passive solar systems in building A, because of changes made during the construction phase. Although the monitoring campaign showed significant thermal benefits from the greenhouses (Boeri and Fabbri, 2014; Giachetta et al., 2014b), only two, instead of four air vents, are actually installed. Moreover, the anemometric analysis of the vents showed a lower air convection than the expected, because of the insufficient air capacity of the selected vents;

- the surveys also highlighted the issues of cleaning and maintenance of the adopted systems, that could affect the effective operation of passive solar systems in the long term; a constant control of the buildings, with the cooperation of users, would be important to

- the surveys found a lack of users' awareness concerning the management and opportunities of electrical air fans in Trombe-Michel walls.

The user manual is a 7-page document addressed to the tenants of the buildings A, B and C, retrofitted with passive solar systems. It is aimed at informing users about the correct behaviour needed to operate and maintain passive solar systems, as well as their opportunities, in the most simple (not-technical) and understandable language as possible. The user manual is divided in two sections, regarding different passive solar systems (greenhouse and Trombe-Michel wall), and each section is also divided in three parts: a brief description on the passive solar system, based on its perception; the explanation of the most correct management of the passive solar system in wintertime; the explanation of the most correct management in summer, together with some 


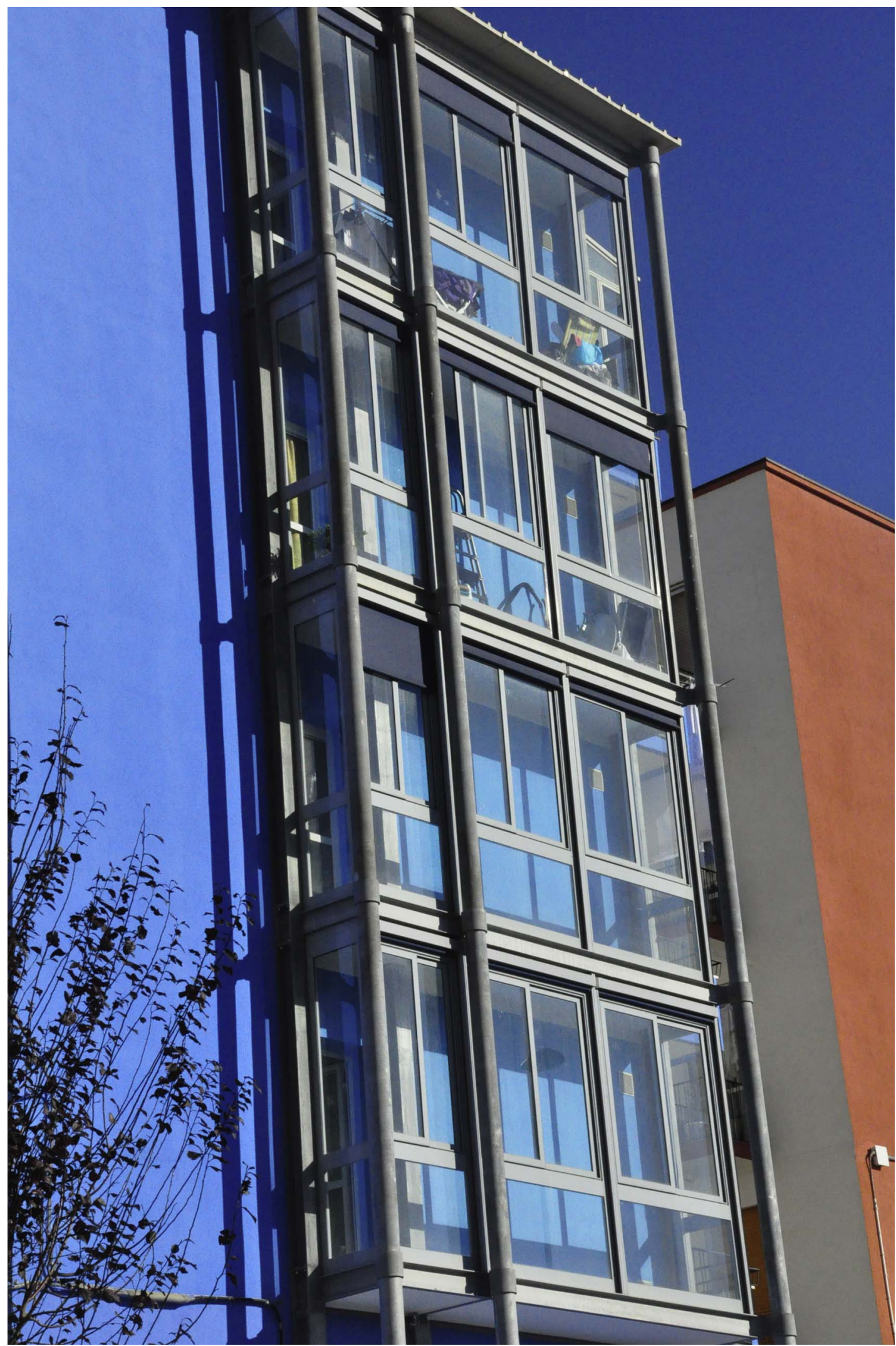

Fig. 1. Building A, South Façade with Solar Greenhouse.gr1

maintenance instructions. The recommendations are based on the description of possible comfort or discomfort sensations felt by the users in their apartment in winter and summer, respectively.
5.2. Smart devices to map and improve tenants/ users behaviour in bolognina district (Bologna - IT)

This case-study is related to Bolognina neighbourhood (34908 


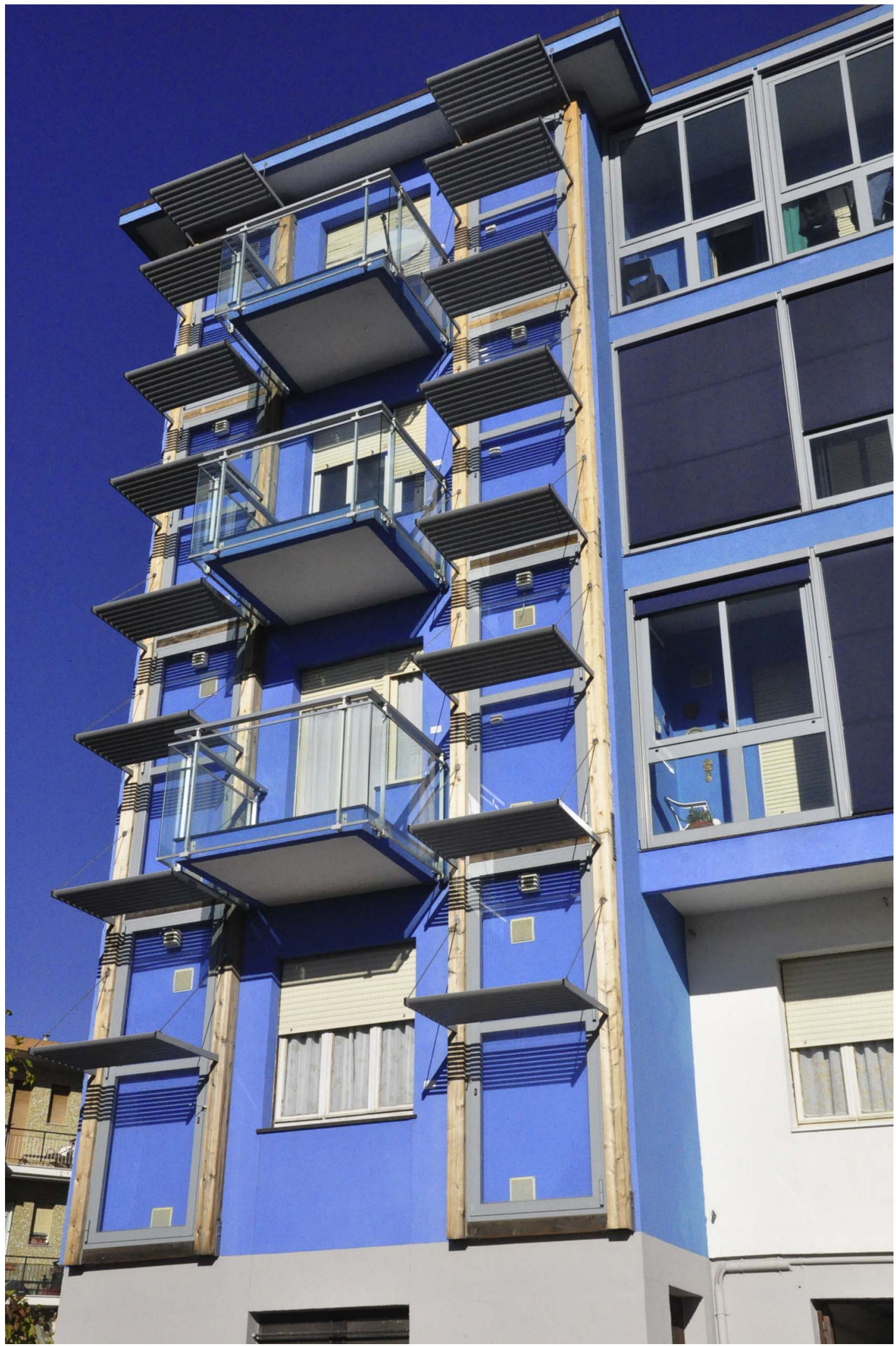

Fig. 2. Building B, South Façade with Solar Greenhouses and Trobe-Michel walls.

inhabitants) in the heart of the Railway area of Bologna which lies in the north of the historic centre, just outside the walls of the downtown. Bolognina is a trial site, where old and new co-exist in a social and urban mix, composed of historic buildings, social housing, but also innovative residential areas, facilities hi-tech and smart services, from a population comprising more than 16 different ethnic groups, that share social spontaneous actions, but also social conflicts. The very peculiar feature of this district is the concentration of housing units for low- 


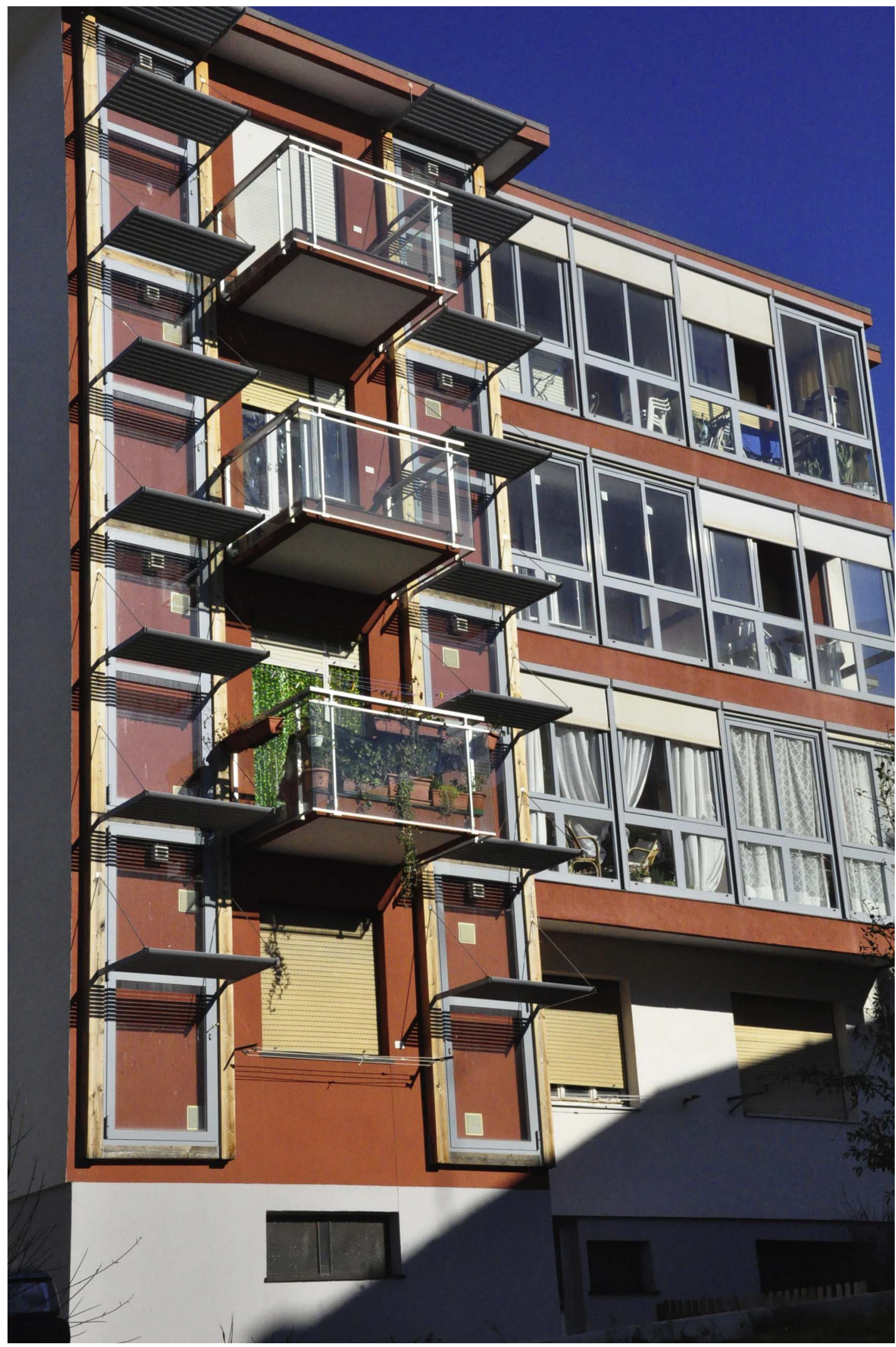

Fig. 3. Building C, South Façade with Solar Greenhouses and Trobe-Michel walls.

income classes (11889 social housing dwellings in Bologna), which is usually connected with remarkable and problematic social issues.

Municipality of Bologna, the Regional Housing Agency (ACER) with the scientific support of the Department of Architecture (DA) of the
University of Bologna (UNIBO) are currently involved in the definition of an experimental study for Bolognina Social Housing with the aim to integrate energy effi ciency measures in renovation actions for existing buildings, with consequent energy savings, $\mathrm{CO}_{2}$ reduction and comfort 
conditions. Therefore, the challenge is to offer affordable housing (public owned) while reducing energy management costs for the Municipality, introducing smart technologies to support a more aware behaviour of final users.

The work started with the identification of the main technical and non-technical barriers to the retrofitting solutions, and through a collaborative study within the two main energy suppliers that act in Bologna (ENEL and HERA), the goal is to find the most effective strategy to overcome these obstacles. The identification phase is comprehensive of field investigations about energy behaviour of three buildings, selected according to a number of criteria considering their relevance, the building typology involved, the replication potential, etc. This analysis elaborated with Termolog tools, will be compared with an on-going tenants' perception analysis about thermal and light comfort in their dwellings, adopting the methodology developed by the DA research group for DIANA kindergarten in Reggio Emilia (Boeri and Fabbri, 2014) and understanding the compliance between perceived and real performance in terms of energy and comfort.

This first investigation step will be completed, following the Savona experience, during a collaborative laboratory promoted at a districtscale by the Municipality of Bologna, with a series of direct interviews to tenants and users to understand their level of awareness about energy savings issues, the use of energy consume control devices, and their availability to test the new technologies developed by the energy supplier companies to map their behaviour and to improve their comfort conditions.

The design strategy is developed according to the following indicators: low cost/cost-effective solutions, fast work-on-site, limited disruption for the end-users, improvement of the building performance, fuel poverty reduction, high replication potential of solutions, low environmental impact according to LCA (Life Cycle Analysis) approach. All the refurbishment solutions and the integration between buildings and smart technologies will follow a user interface design process, which focus on usability goals and user characteristics. The usability goals are related to: 1 . usefulness considering needs of user; 2 . learnability, intended as user's ability to operate the after some predetermined period of training (i.e thanks the help of specific Living Labs in the district); 3. attitude (likeability) based on user's perceptions, feelings and opinions about smart products. Although the use of smart technologies could require a high level of user consciousness (as mentioned above), the use of user-friendly Information and Communication Technologies (ICT) can help the users not only in properly using the devices but also in empowering them to manage their own energy consumption

The smart solutions developed from the suppliers are addressed to electric energy and thermal one. They have thought a customer interface that will be installed in the residential buildings, integrated with the smart meters and able to provide clear and real time information about energy consumptions to tenants. In particular, it will allow to test energy efficiency measures in buildings and enable Active Demand services. The smart solutions would contribute to the increasing of energy effi ciency and to the reduction of energy bill as a consequence of customers awareness about energy consumption, signalling, through appropriate notices in an app the presence of behaviours energetically little virtuous, thus giving the user the possibility to modify them with consequent cost savings.

The Municipality during Living Lab activities will support the communities of tenants in the comprehension and the usability of these smart devices, with the direct support of the University and the energy suppliers. The project will be supported by monitoring activities to evaluate impacts and changes.

\section{Conclusion}

This paper points out the need to overpass the consolidated approach adopted nowadays for design assessments foreseeing the application of numerical tools for buildings that have a known close interaction of the user with the building (Hoes et al., 2009), with a multidisciplinary approach, able to improve the understanding of the relationship between users and technological devices. This relation can be compromised in the future by the increased complexity of technological solutions (especially due to the use of non-traditional construction techniques and sophisticated smart energy-saving devices), so it is necessary to consider these research fields according to a systemic approach. The use of emerging technologies has to meet some primary needs, such as housing quality and flexible housing and service spaces (functional requirements), and at the same time requires specific design expertise and construction know-how, so ensuring long-lasting performance and avoiding premature disrepair (technological requirements); moreover, it is important that the users assimilate and accept emerging technologies in order to ensure a good living comfort and the correct operation of these technologies (social acceptability requirements). In particular, the use of emerging technologies in social housing interventions may require a deep reflection on social and cultural implications and on the users' behaviour and its impacts, since the tenants are not always able to recognise and understand the technological systems used and sensitive to their advantages.

In Social Housing field, the end-users necessarily become the focus of design process and management activities of the building heritage. The use of emerging technologies has to become inclusive and accepted by their users, in order to ensure living comfort and durability of the building performances.

It's crucial before design stage to investigate the dimension and the value of end users behaviour, in the achievement of good performance of buildings, and to identify the best strategies to forecast and minimize negative impacts of tenant's habits on the good use and functioning of dwelling technologies.

For this reason, research studies have to consider a multidisciplinary of approach, which include social competencies to increase public participation strategies and user's awareness in the design process, as well as ICT and energy suppliers cooperation to define design tools and support measure for tenants with the aim to improve a better relationship between user and technological system (and so a better housing quality).

The introduction of these elements can support more functional and contextualized choices about the technologies employed, helping energy accessibility strategies in social housing sector, which require an effective use of energy with the minimum purpose of economic and technological resources.

Funding

This research did not receive any specific grant from funding agencies in the public, commercial, or not-for-profit sectors.

\section{References}

https:// ec.europa.eu/energy/en/topics/energy-efficiency/ buildings.

http:// beca-project.eu/home.html.

http:// cabee.regio-v.at.

Alexander, S., \& Yacoumis, P. (2016). energy descent, and 'low-tech' living: potential pathways for increased resilience in times of crisis. Journal of Cleaner Production, 1-9 (in press.

Bakhaus, J., \& Heiskanen, E. (2013). Research Note 2: Rating expert advice on how to change energy behaviour. European Commissionor energy saving with lighting and HVAC services, Frontiers of Architectural Research.

Banfill, P. F. G., \& Peacock, A. D. (2007). Energy-eff cient new housing - the UK reaches for sustainability. Building Research and Information, 35, 426-436.

Boeri, A., \& Fabbri, K. (2014). IAQ evaluation in kindergarten: the Italian case of Asilo Diana. in Advances in Building Energy Research, 8(2), 241-258.

Boeri, A., Antonini, E., \& Longo, D. (2013). Edilizia abitativa ad alta densità. Strumenti di Analisi e Strategie di Rigenerazione. Mondadori, Milano: Il quartiere Pilastro a Bologna.

Bradford, B., \& Schleich, J. (2012). Residential energy-effi cient technology adoption, energy conservation, knowledge, and attitudes: an analysis of European countries. Energy Policy, 49, 616-628.

Brown, P., Swan, W., \& Chahal, S. (2014). Retrofitting social housing: reflections by 
tenants on adopting and living with retrofit technology. Energy Efi ciency, 7(4), $641-653$.

Chwieduk, D. (2003). Towards sustainable-energy buildings. Applied Energy, 76, 211-217.

Collier, A., Cotterill, A., Everett, T., Muckle, R., Pike, T., \& Vanstone, A. (2010).

Understanding and influencing behaviours: a review of social research. Economics and Policy Making in Defra.

Darby, S. (2010). Smart metering: what potential for householder engagement. Building Research and Information, 38(5), 442-457.

E.U. Commission (2008). Communication from the Commission: energy efficiency: delivering the $20 \%$ target. Brussels: Commission of the European Communities. [Available at:] http:/ / eur-lex.europa.eu/ LexUriServ/ LexUriServ.do?uri= COM:2008:0772:FIN:EN:PDF.

EEA (2013). Achieving energy effi ciency through behaviour change: what does it take? EEA Technical Report [n.5/].

EPBD (2010). Directive 2010/31/ EU of the European Parliament and of Council of 19 May 2010 on the energy performance of buildings (recast). Off cial Journal of the European Union.

Elzenga, J., Voordijk, J., Hartmann, T., \& Salet, T. (2010). Occupancy based energy simulation for meaningful design decision making. University of Twente: VISICO Center.

Galvin, R. (2014). Making the 'rebound effect' more useful for performance evaluation of thermal retrofits of existing homes: defining the 'energy savings deficit and the energy performance gap. Energy and Buildings, 69, 515-524.

Giachetta, A., Piccardo, C., \& Magliocco, A. (2014a). Monitoring of passive solar systems in retrofitted buildings. In advanced building skins ? conference proceedings of the 9 th ENERGY FORUM (pp. 909-923).

Giachetta, A., Magliocco, A., \& Piccardo, C. (2014b). Performance of passive solar system in a case of retrofitted buildings. In T. Papanikos Gregory (Ed.), Architecture abstracts. 4th annual international conference on architecture, athens institute for education and research (ATINER) (pp. 77-).

Giachetta, A. (2012). Solar retrofitting in social housing: a case study in Savona. Techne, $4,366-373$.

Gianfrate, V., \& Piccardo, C. (2016). Qualità dello spazio: sistemi e tecnologie per nuove spazialità e nuovi modi di abitare/Space quality: systems and technologies for new spaces and living models, in Cluster in progress. In E. Lucarelli, \& C. Mussinelli (Eds.), La Tecnologia dell'architettura in rete per l'innovazione/ The Architectural technology network for innovation (pp. 320-327). MAGGIOLI.

Gianfrate, V., Antonini, E., Longo, D., \& Copiello, S. (2016). Challenges for public-Private partnerships in improving energy efficiency of building sector. International Housing Science Journal, 40-02, 99-1 10 .

Gill, Z M., Tierney, M. J., Pegg, I. M. \& Allan, N. (2010). Low-energy dwellings: the contribution of behaviours to actual performance. Building Research and Information, 38, 491-508.

Harvey, L. D. D. (2010). Energy and the new reality 1. Energy effi ciency and the demand for energy services. London: Earthscan.

Hertwich, E. G. (2005). Consumption and the rebound effect: an industrial ecology perspective. Journal of Industrial Ecology, 9, 85-98.

Hoes, P., Hensen, J. L. M., Loomans, M. G. L. C., Vries de, B., \& Bourgeois, D. (2009). User behavior in whole building simulation. Energy and Buildings, 41(3), 295-302.

Hong, T., Taylor-Lange, S. C., D’Oca, S., \& Yanc Da Corgnati, S. P. (2016). Advances in research and applications of energy-related occupant behavior in buildings. Energy and Buildings, 116, 694-702.

I.P.C.C (2014). Climate change 2014: mitigation of climate change. Contribution of working group III to the fifth assessment report of the intergovernmental panel on climate change http:// www.ipcc.ch.

Janda, K. B. (2009). Buildings don't use energy, people do. C. M. H. Demers, \& A. Potvin (Eds.). Proceedings of the 26 th international conference on passive and low energy architecture (PLEA), university of laval press quebec city, 9-14.

Jenkins, D. P. (2010). The value of retrofitting carbon-saving measures into fuel poor social housing. Energy Policy, 38(2), 832-839.

Kolaitis, D. I., Malliotakis, E., Kontogeorgos, D. A., Mandilaras, I., Katsourinis, D. I., \& Founti, M. A. (2013). Comparative assessment of internal and external thermal insulation systems for energy e fficient retrofitting of residential buildings. Energy and Buildings, 64, 123-131.
Lodi Rizzini, C. (2013). Il social housing e i nuovi bisogni abitativi, in 2WEL, Primo rapporto sul secondo welfare 2 in Italia. 1-34 [available at: http:// secondowelfare.it/ edt/file/ 1R2W_CAP8_LODI RIZZINI_Social_housing e nuovi bisogni_abitativi.pdf (Accessed October 15 2015).]

Lomas, H., Martin, C., \& Bloomfield, D. (1997). Empirical validation of building energysimulation programs. Energy and Buildings, vol. 26(3), 253-275.

Ma, Z., Cooper, P., Daly, D., \& Ledo, L. (2012). Existing building retrofits: methodology and state-of-the-art. Energy and Buildings, 55, 889-902.

Magliocco, A., \& Giachetta, A. (2011). Riqualificazione energetica di edifici di edilizia residenziale pubblica sovvenzionata a Savona (Italian). IlProgettoSostenibile, 28, $40-45$.

Midden, C., Kaiser, F., \& McCalley, T. (2007). Technology's four roles in understanding individuals' conservation of natural resources. Journal of Social Issues, 63, 155-174.

Milne, G., \& Boardman, B. (2000). Making cold homes warmer: the effect of energy efficiency improvements in low-income homes a report to the EAGA Charitable Trust. Energy Policy, 28, 411-424.

Napoli, G. (2015). The economic sustainability of residential location and social housing An application in Palermo city. XLIII incontro di studio del Ce.S.E.T. 257-277.

Nemry, F., \& Uihlein, A. (2008). Environmental improvement potentials of residential buildings (IMPRO-Building). Luxembourg: Office for O $f_{i}$ cial Publications of the European Communities. [Available at] http:// ftp.jrc.es/EURdoc/ JRC46667.pdf.

Nomisma La condizione abitativa in Italia, Dalle esperienze di housing sociale alla risposta del Piano Nazionale di Edilizia Abitativa e del Piano Casa, 2(Rapporto Nomisma Libri per l'Economia, 2010.

Norris, M., \& Shiels, P. (2004). Regular national report on housing developments in European countries. Synthesis reportDublin, Ireland: The Housing Unit.

Pedrini, A., Westphal, F., \& Lamberts, R. (2002). A methodology for building energy modelling and. calibration in warm climates. Building and Environment, vol. 37, 903-912.

Petersdorff, C., Boermans, T., \& Harnisch, J. (2006). Mitigation of CO2 emissions from the EU-15 building stock: beyond the EU Directive on the Energy Performance of Buildings. Environmental Science and Pollution Research, 13(5), 350-358.

Pothitou, M., Kolios, A. J., Varga, L., \& Gu, S. (2016). A framework for targeting household energy savings through habitual behavioural change. International Journal of Sustainable Energy, 35(7), 686-700.

Ryghaug, M., \& Sørensen, K. H. (2009). How energy efficiency fails in the building industry. Energy Policy, 37, 984-991.

Shove, E. (2010). Beyond the ABC: climate change policy and theories of social change. Environment and Planning A, 1273-1285.

Smith, W., \& Pett, J. (2005). Energy effi ciency refurbishment programmes help, but are the end- users doing their bit? London: Association for the Conservation of Energy.

Steemers, K., \& Yun, G. Y. (2009). Household energy consumption: a study of the role of occupants. Building Research \& Information, 37(5-6), 625-637.

Stevenson, F., \& Leaman, A. (2010). Evaluating housing performance in relation to human behaviour: new challenges. Building Research \& Information, 38, 437-441.

Thomson, H., \& Snell, C. (2013). Quantifying the prevalence of fuel poverty across the European Union. Energy Policy, 52(issue C), 563-572.

Tommerup, H., \& Svendsen, S. (2006). Energy saving in Danish residential building stock. Energy and Buildings, 38, 618-626.

Tronchin, L. \& Fabbri, K. (2008). Energy performance building evaluation in mediterranean countries: ries: Comparison between software simulations and operating rating simulation. Energy and Buildings, vol. 40(7), 1176-1187.

Uihlein, A., \& Eder, P. (2010). Policy options towards an energy effi cient residential building stock in the EU. Energy and Buildings, 42(6), 791-798.

Visscher, H., Sartori, I., \& Dascalaki, E. (2016). Towards an energy effi cient European housing stock: monitoring, mapping and modelling retrofitting processes. of Energy and Buildings. Energy and Buildings, 79, 1-3 [Special issue (in press)].

Whitehead, C., \& Scanlon, K. J. (2007). Social housing in europe. London: London School of Economics and Political Science.

Xing, Y., Hewitt, N., \& Griffi ths, P. (2011). Zero carbon buildings refurbishment. A Hierarchical pathway. Renewable and Sustainable Energy Reviews, 15(6), 3229-3236.

Yohanis, Y. G. (2012). Domestic energy use and householders' energy behaviour. Energy Policy, 41, 654-665. 